\title{
DEVELOPING A MULTIREPRESENTATION LEARNING MODEL BASED ON LOCAL WISDOM TO TRANSFORM CHARACTER FOR STUDENTS OF 5-6 YEARS OLD
}

\author{
Novianti Retno Utami ${ }^{1)}$, Khikmah Novitasari ${ }^{2}$ ) \\ PG-PAUD UNIVERSITAS PGRI YOGYAKARTA \\ novianti@upy.ac.id
}

\begin{abstract}
This research aimed to: (1) develop a multirepresentation learning model, (2) reveal the effectiveness of the developed multirepresentation learning model, and (3) transform character for students of 5-6 years old. The data were collected using a validation sheet, questionnaire of teacher's responses, and observation. The data were analyzed using the independent sample $t$ test with a significance level of 0,05. The result of the assessment by the material expert validator was "Good". The research finding revealed that the multirepresentation learning model in terms of the content expediency, the language, the presentation, and the graphic component were categorized "Very Good". There was a difference in the nation spirit character between the experimental class and the control class after the teacher used the multirepresentation learning model with $\mathrm{p}<0.05$, and there was also a significant increase, with $\mathrm{p}=$ 0.000 .
\end{abstract}

Keywords: multirepresentation learning model, local wisdom, early childhood

\section{PENGEMBANGAN MODEL PEMBELAJARAN MULTIREPRESENTASI BERBASIS KEARIFAN LOKAL UNTUK MEMBENTUK KARAKTER PESERTA DIDIK USIA 5-6 TAHUN}

\begin{abstract}
Abstrak: Penelitian ini bertujuan untuk: (1) menghasilkan produk berupa model pembelajaran multirepresentasi untuk peserta didik usia 5-6 tahun, (2) memperoleh informasi mengenai keefektifan model pembelajaran multirepresentasi yang dikembangkan untuk peserta didik usia 5-6 tahun, dan (3) membentuk karakter untuk peserta didik usia 5-6 tahun. Pengumpulan data menggunakan lembar validasi, angket respon guru, dan lembar observasi. Hasil penilaian oleh validator ahli materi mendapatkan kriteria "Baik". Hasil penelitian menunjukkan bahwa buku panduan ditinjau dari komponen kelayakan isi, kebahasaan, penyajian, dan kegrafikaan berkategori "Sangat Baik". Teknik analisis data menggunakan independent sample t-test dengan taraf signifikansi 0,05. Terdapat perbedaan hasil akhir antara kelas kontrol dan kelas eksperimen setelah guru menerapkan model pembelajaran multirepresentasi berbasis kearifan lokal dengan $\mathrm{p}$ $<0,05$ kemudian terjadi pula peningkatan yang signifikan dengan $\mathrm{p}=0,000$.
\end{abstract}

Kata Kunci: model pembelajaran multirepresentasi, kearifan lokal, anak usia dini

\section{PENDAHULUAN}

Permasalahan yang perlu menjadi perhatian baru-baru ini adalah kecenderungan masyarakat khususnya generasi muda dalam mengadopsi berbagai pengaruh budaya asing tanpa menyaringnya terlebih dahulu. Fenomena yang bertentangan dengan pembentukan karakter semakin marak bahkan sangat meresahkan. Kondisi demikian menunjukkan adanya krisis jati diri, dan krisis kepribadian nasional, atau bisa juga disebut krisis kebudayaan.

Kondisi demikian menunjukkan betapa bangsa ini sedang mengalami degradasi karakter, khususnya karakter kecintaan terhadap tanah air bangsa. Persoalan ini perlu penanganan dengan tepat karena sifatnya yang krusial. Salah satu upaya untuk menanganinya adalah 
dengan menerapkan pendidikan karakter.

Karakter mengacu pada konstelasi sikap, perilaku, motivasi, dan keterampilan yang jauh lebih luas. Ini lebih dari sekadar menghindari keterlibatan dalam perilaku yang tidak diinginkan secara sosial. Karakter mencakup sikap seperti keinginan untuk melakukan yang terbaik dan memperhatikan kesejahteraan orang lain; kapasitas intelektual seperti pemikiran kritis dan penalaran moral; perilaku seperti jujur dan bertanggung jawab, dan berdiri untuk prinsip-prinsip moral dalam menghadapi ketidakadilan; keterampilan interpersonal dan emosional yang memungkinkan untuk berinteraksi secara efektif dengan orang lain dalam berbagai situasi; dan komitmen untuk berkontribusi pada komunitas dan masyarakat. Secara sederhana, karakter adalah perwujudan dari perkembangan positif seseorang sebagai pribadi - secara intelektual, sosial, emosional, dan etis (Battistich, 2011) [1].

Pendidikan karakter didefinisikan sebagai penggunaan yang disengaja dari semua dimensi kehidupan sekolah untuk mendorong pengembangan karakter yang optimal. Pendekatan komprehensif untuk pendidikan karakter ini menggunakan setiap aspek pendidikan yaitu isi kurikulum, proses pengajaran, kualitas hubungan, penanganan disiplin, pelaksanaan kegiatan kokurikuler dan etos lingkungan sekolah total hingga menumbuhkan karakter baik di semua anggota sekolah. Sambil mengakui peran utama yang dimainkan oleh orang tua dalam pengembangan karakter anakanak mereka, kami juga menegaskan peran penting yang harus dimainkan sekolah dalam meningkatkan pengembangan karakter siswa dan mempersiapkan mereka untuk menjadi warga negara yang efektif (Battistich, 2011) [1].
Pendekatan komprehensif untuk pendidikan karakter ini menggunakan setiap aspek pendidikan yaitu isi kurikulum, proses pengajaran, kualitas hubungan, penanganan disiplin, pelaksanaan kegiatan kokurikuler dan etos lingkungan sekolah total hingga menumbuhkan karakter baik di semua anggota sekolah. Lickona, Schaps, \& Lewis (2003) [2] juga mengungkapkan pentingnya keterlibatan keluarga dan anggota masyarakat sebagai mitra dalam pendidikan karakter. Pendekatan tersebut dapat dituangkan ke dalam suatu model pembelajaran. Model pembelajaran menjadi sangat penting dalam proses pembelajaran karena menjadi faktor dominan dalam proses keberhasilan sebuah proses pembelajaran. Salah satu model pembelajaran yang dapat diterapkan adalah model pembelajaran multirepresentasi.

Model pembelajaran multirepresentasi merupakan salah satu model yang dapat diterapkan dalam pendidikan karakter. Representasi merupakan penyajian ulang suatu informasi yang dapat berbentuk oral, simbol, atapun piktorial. Kata "multi" mengacu pada ragam atau jenis sajian representasi. Sehingga secara epistimologi, multirepresentasi dapat didefinisikan sebagai representasi informasi ke dalam berbagai bentuk baik secara visual maupun verbal. Menurut Ainsworth (1999) [3] menggunakan lebih dari satu representasi (multirepresentasi) dapat menangkap minat pembelajar dan memainkan peran penting dalam meningkatkan kondisi pembelajaran yang efektif.

Sejalan dengan Ainsworth, Wu-Yuin Hwang, dkk (2007) [4] mengatakan bahwa multirepresentasi sebagai sebuah formulasi proses dalam mengartikulasi permasalahan yang sama dalam bentuk yang 
berbeda. Multirepresentasi merupakan kemampuan untuk mengartikulasi permasalahan yang sama ke dalam bentuk yang berbeda agar dapat lebih dipahami dan ditemukan sketsa pemecahan yang lebih tepat. Artikulasi yang dimaksud lebih merujuk pada kemampuan mengubah suatu hal menjadi bentuk lain baik secara fisik atau non fisik (konsepsi) yang lebih familiar agar lebih dapat dikenal dan dipahami seseorang.

Penerapan model pembelajaran multirepresentasi ini menekankan bagaimana pengelolaan peserta didik dalam melakukan pengkodean informasi mengenai nilai-nilai kearifan lokal untuk disimpan ke dalam memori jangka panjang dan dapat dikeluarkan kembali sewaktu-waktu jika diperlukan. Proses menyimpan ke dalam memori, membutuhkan kode alamiyah yang terprogram dalam otak, sehingga seseorang dapat mengeluarkan apa yang telah diingat dan disimpannya walaupun dalam waktu yang lama.

Mungmachon (2012:176) [5] menyebutkan bahwa kearifan lokal merupakan pengetahuan dasar yang diperoleh dari hidup seimbang dengan alam. Menjaga keseimbangan dan kelestarian alam sama artinya kita telah menjaga kearifan lokal. Umar (2015:70) [6] kemudian menekankan bahwa kearifan lokal sebagai pengetahuan serta nilai-nilai yang terseleksi dan memiliki nilai kebenaran yang masih berlaku dalam suatu masyarakat yang memberikan spirit dan kekuatan dalam pengembangan masyarakat. Nilai kearifan lokal yang dimiliki oleh setiap masyarakat ini yang menjadikan setiap daerah memiliki identitas tersendiri dalam menunjukkan karakteristik dari setiap daerah itu sendiri. Kearifan lokal yang dimiliki oleh masyarakat bisa berbentuk lagu-lagu, peribahasa, nasihat, semboyan dan kebiasaan yang ada pada masyarakat itu sendiri.
Sehubungan dengan hal itu, dalam konteks pembelajaran maka dibutuhkan suatu kondisi dimana lingkungan belajar dapat dimodel agar proses pembentukan karakter lebih cepat dan efektif dilakukan oleh otak. Dalam hal ini, multirepresentasi memodelkan lingkungan belajar yang kaya dan produktif yang dapat menopang cara kerja otak terutama dalam proses mengingat (memorizing). Karena sebagaimana diketahui bahwa multirepresentasi merupakan proses penyajian atau pengabstraksian ulang suatu pengetahuan, informasi, atau suatu konsep ke dalam beberapa bentuk yang berbeda dengan bentuk sebelumnya baik secara verbal (oral) maupun visual (simbolik, piktorial) sehingga pengetahuan tersebut dapat ditranslasikan lebih lanjut ke arah pemahaman yang lebih mendalam sesuai dengan gaya atau kecenderungan pemerosesan informasi yang dimiliki peserta didik.

Berdasarkan uraian di atas, dapat disimpulkan bahwa fungsi multirepresentasi lebih mengarah pada dukungan terhadap proses pembentukan karakter yang menempatkan peserta didik untuk berada dalam keadaan yang ideal dalam mencerna suatu informasi, mendorong kejelasan interpretasi yang terjadi ketika memproses informasi, serta membantu untuk membangun pemahaman yang mendalam mengenai informasi tersebut. Pembelajaran tidak hanya menerapkan cara-cara konvensional tetapi dengan kata-kata, gambar, video atau praktek secara langsung dalam pembelajaran ataupun bersentuhan langsung dengan materi yang akan dipelajari.

\section{METODE PENELITIAN}

Penelitian ini bertujuan untuk mengembangkan model pembelajaran 
agar pembentukan karakter dapat dicapai dengan optimal oleh peserta didik. Untuk itu, dalam hal ini peneliti menggunakan prosedur research and development. Berdasarkan apa yang disampaikan Borg \& Gall, produk yang dihasilkan prosedur ini tidak hanya buku panduan pembelajaran, akan tetapi juga menghasilkan suatu model pembelajaran. Luaran penelitian berupa buku panduan yang berisi pelaksanaan model secara keseluruhan yaitu sintaks model baik secara konseptual maupun prosedural, pengembangan materi dan bahan ajar untuk guru, rencana pelaksanaan pembelajaran, media pembelajaran, serta instrumen penilaian.

Untuk mencapai tujuan penelitian, secara keseluruhan peneliti mengadopsi metode penelitian dan pengembangan dengan tahap penelitian sebagai berikut: 1) tahap studi pendahuluan, 2) tahap pengembangan model, 3) tahap validasi dan revisi model, dan 4) tahap implementasi model-model.

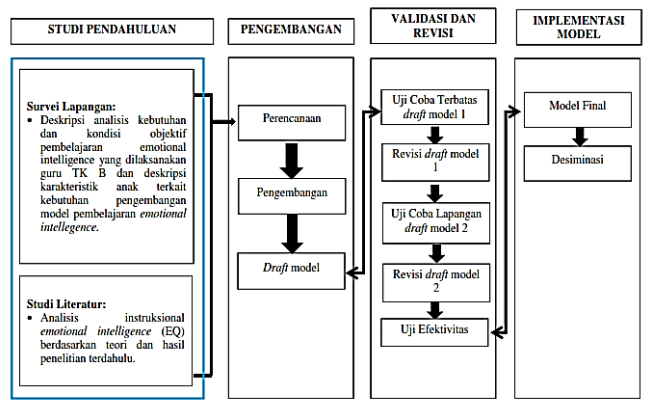

Gambar 1. Diagram Tahap Pengembangan Model

\section{HASIL DAN PEMBAHASAN}

\section{A. Hasil Pengembangan Produk Awal}

Penelitian ini bertujuan mengembangkan model pembelajaran multirepresentasi berbasis kearifan lokal untuk membentuk karakter anak usia 5-6 tahun. Penelitian yang digunakan adalah penelitian dan pengembangan dengan mengadaptasi metode pengembangan Borg \& Gall (2007) [7] yang disederhanakan menjadi 7 langkah dari 10 langkah utama dalam penerapan sebuah penelitian pengembangan. Langkah pengembangan yang digunakan tersebut dibagi menjadi 3 tahapan utama yaitu studi pendahuluan, pengembangan produk, dan uji coba. Ada beberapa tahap yang harus dilakukan sebelum membuat produk awal dari produk yang dikembangkan.

\section{Hasil Studi Pendahuluan (Analisis Kebutuhan) \\ Analisis kebutuhan merupakan} proses yang sistematis untuk menentukan tujuan, mengidentifikasi masalah, dan menentukan prioritas yang akan dilakukan. Terdapat beberapa langkah yang dapat membantu untuk melakukan analisis kebutuhan, antara lain dengan melihat kondisi yang terjadi, menegaskan hal yang akan dilakukan, dan menyusun prioritas yang akan dilakukan. Dalam hal ini, peneliti menggunakan metode wawancara untuk menganalisis kebutuhan di lapangan. Wawancara dilakukan di TK ABA Kembaran dan TK ABA Godegan di Kecamatan Kasihan untuk mengetahui apa saja kendala yang ditemui oleh guru dalam pelaksanaan pembelajaran khususnya dalam pembentukan karakter cinta tanah air pada anak usia 5-6 tahun. Berdasarkan hasil kebutuhan yang dilakukan melalui wawancara didapatkan bahwa:

Pertama, secara umum proses pembelajaran yang ada di TK ABA Kembaran dan TK ABA Godegan Kecamatan Kasihan telah menekankan tentang penanaman nilainilai karakter akan tetapi karakter cinta tanah air belum ditekankan dalam pembelajaran.

Kedua, potensi lokal belum diterapkan dalam proses kegiatan pembelajaran. Penerapan potensi lokal dalam pembelajaran di PAUD sudah diatur di dalam Permendikbud Nomor 137 Tahun 2014 [8] tentang 
ketentuan umum penerapan pembelajaran PAUD. Akan tetapi dalam proses pembelajaran belum mengedepankan potensi lokal sebagai muatan materi pembelajarannya.

Ketiga, dari wawancara yang dilakukan di kedua sekolah, diketahui bahwa pembentukan karakter dilakukan dengan metode pembiasaan dan keteladanan. Akan tetapi, guru masih kesulitan untuk membentuk karakter cinta tanah air. Sehingga, dibutuhkan suatu model pembelajaran yang dapat efektif untuk mengembangkan karakter cinta tanah air pada peserta didik, yaitu pembelajaran yang tidak hanya melalui satu representasi, tetapi menerapkan multirepresentasi, yaitu dengan katakata, gambar, video atau praktek secara langsung ataupun bersentuhan langsung dengan materi yang akan dipelajari.

Dari hasil tersebut, peneliti mempunyai pemikiran untuk mengembangkan pembelajaran yang dipadukan dengan potensi lokal daerah yang ditekankan dalam kearifan lokal. Kearifan lokal yang digunakan adalah dolanan anak, pakaian adat Yogyakarta, dan makanan tradisional khas Yogyakarta. Pengembangan pembelajaran multirepresentasi berbasis kearifan lokal ini disesuaikan dengan prinsip pembelajaran dan karakter anak usia dini. Untuk mempermudah guru dalam menerapkan model pembelajaran multirepresentasi berbasis kearifan lokal, maka peneliti juga akan mengembangkan buku panduan beserta contoh perangkat pembelajarannya. Dalam buku panduan, mulai dari persiapan, pelaksanaan dan evaluasi pembelajaran diuraikan secara lengkap.

\section{Deskripsi Draft Produk Awal}

Model pembelajaran multirepresentasi berbasis kearifan local yang dikembangkan merupakan kisi-kisi dengan kerangka dari model konseptual yang telah dirumuskan. Target penerapan model pembelajaran multirepresentasi ini adalah anak usia 5-6 tahun (kelompok B). Produk yang dikembangkan berupa model pembelajaran multirepresentasi berbasis kearifan local yang dikemas dalam buku panduan.

Berikut keterangan langkahlangkah atau sintaks yang tersusun secara sistematis dan logis pada model pembelajaran multirepresentasi berbasis kearifan local pada anak usia 5-6 tahun:

\section{a. Penentuan tema dan subtema}

Tema digunakan pada pembelajaran anak usia dini adalah untuk membangun pengetahuan pada anak dan mengembangkan seluruh aspek perkembangan anak. Dalam mengembangkan tema, hal yang penting untuk diperhatikan adalah bagaimana membangun pengetahuan secara sistematik dan holistik. Pada model pembelajaran multirepresentasi berbasis kearifan local ini, tema yang diambil adalah "Yogyakarta". Sedangkan untuk subtemanya adalah "Dolanan tradisional", "Makanan tradisional khas Yogyakarta", dan "Baju adat Yogyakarta".

\section{b. Pembuatan Peta Konsep Pengetahuan}

Peta konsep pengetahuan merupakan rincian materi dari subsubtema dalam satu hari yang akan disampaikan kepada anak, agar dapat terurai dengan jelas. Prinsip pembuatan peta konsep pengetahuan menggunakan $5 \mathrm{~W}+1 \mathrm{H}$.

\section{c. Pengembangan kegiatan melalui pembelajaran multirepresentasi}

1) Kegiatan pembuka/ apersepsi

a) Anak berbaris

b) Guru mengajak anak untuk melakukan kegiatan fisik

c) Berdoa dalam circle time, bernyanyi, tanya jawab, apersepsi 
2) Kegiatan inti

Pada kegiatan inti, kegiatan pembelajaran yang diberikan melalui multirepresentasi, yaitu tidak hanya belajar dengan katakata, tetapi anak terlibat langsung dalam aktivitas, dan menggunakan sarana audiovisual.

3) Kegiatan penutup

Kegiatan penutup dilakukan dengan mengkomunikasikan hasil, melakukan refleksi pembelajaran, dan pemberian pesan moral. Setelah itu, maka anak berdoa dan diperbolehkan pulang.

Desain draft model pembelajaran multirepresentasi berbasis kearifan local di atas merupakan desain draft awal produk dan dilanjutkan dengan penyusunan buku panduan. Produk berupa buku panduan penerapan model pembelajaran multirepresentasi berbasis kearifan local merupakan buku yang digunakan oleh guru sebagai panduan dalam melakukan kegiatan pembelajaran, sehingga guru dapat mengimplementasikan secara mandiri dalam proses pembelajaran. Buku panduan yang dikembangkan memiliki komponen berikut ini:

a. Cover buku panduan

b. Kata pengantar

c. Daftar Isi

d. Pendahuluan

e. Sintaks model pembelajaran kearifan lokal

f. Kegiatan pembelajaran kearifan lokal

1) Dolanan Anak

2) Makanan Tradisional Khas Yogyakarta

3) Pakaian Adat Yogyakarta

g. Profil Penulis

h. Lampiran Perangkat Pembelajaran
Berikut ini dipaparkan hasil rancangan produk final buku panduan:

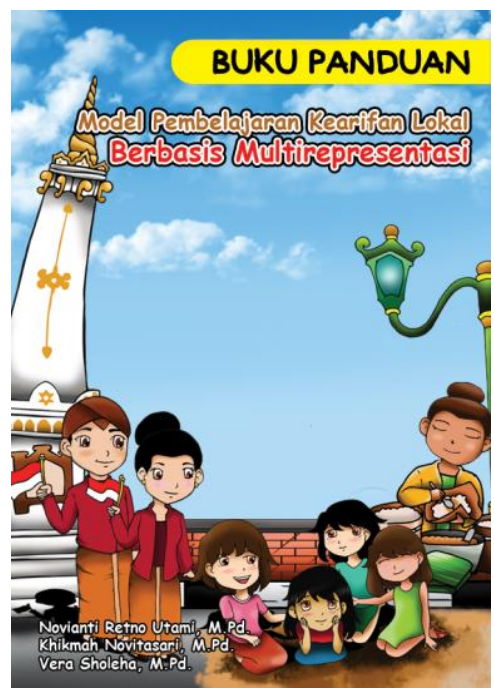

Gambar 2. Cover Depan Buku Panduan

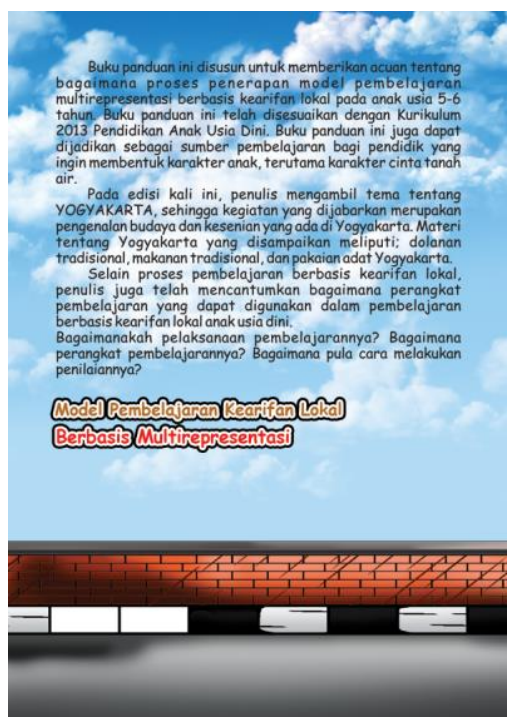

Gambar 3. Cover Belakang Buku Panduan

B. Hasil Uji Coba Produk

1. Uji Validasi

a. Data Validasi dan Kelayakan Draft Produk Awal oleh Ahli Draft awal model pembelajaran multirepresentasi berbasis kearifan lokal ini dasarnya menekankan tentang pembentukan nilai-nilai karakter terutama karakter cinta tanah air yang didasari dengan kearifan lokal Yogyakarta. Terdapat 3 
aspek penting yang dinilai validator terhadap draft produk yang dikembangkan yang terdiri dari 13 butir pernyataan. Adapun hasil penilaian yang didapatkan dari ahli adalah sebagai berikut:

Tabel 1. Hasil Validasi Ahli terhadap

Draft Produk Model Pembelajaran

Multirepresentasi Berbasis Kearifan

Lokal untuk Pembentukan Karakter

\begin{tabular}{|c|c|c|c|}
\hline No. & Item Soal & Skor & Keterangan \\
\hline \multicolumn{4}{|c|}{ MATERI } \\
\hline 1 & $\begin{array}{l}\text { Kesesuaian } \\
\text { rasionalisasi model } \\
\text { pembelajaran } \\
\text { dengan kurikulum } \\
\text { pembelajaran }\end{array}$ & 4 & Baik \\
\hline 2 & $\begin{array}{l}\text { Kesesuaian konsep } \\
\text { pembelajaran } \\
\text { multirepresentasi } \\
\text { dengan proses } \\
\text { pembelajaran }\end{array}$ & 4 & Baik \\
\hline 3 & $\begin{array}{l}\text { Kesesuaian tujuan } \\
\text { model pembelajaran }\end{array}$ & 4 & Baik \\
\hline 4 & $\begin{array}{l}\text { Kesesuaian materi } \\
\text { model pembelajaran }\end{array}$ & 4 & Baik \\
\hline 5 & $\begin{array}{l}\text { Kesesuaian dan } \\
\text { kelengkapan sintaks } \\
\text { pembelajaran }\end{array}$ & 4 & Baik \\
\hline 6 & $\begin{array}{l}\text { Kesesuaian } \\
\text { kegiatan guru dan } \\
\text { anak dalam proses } \\
\text { pembelajaran }\end{array}$ & 5 & Sangat baik \\
\hline 7 & $\begin{array}{l}\text { Kesesuaian } \\
\text { penilaian kegiatan } \\
\text { pembelajaran }\end{array}$ & 5 & Sangat baik \\
\hline \multicolumn{4}{|c|}{ SINTAKS } \\
\hline 8 & $\begin{array}{l}\text { Kejelasan kegiatan } \\
\text { pendahuluan }\end{array}$ & 3 & Cukup \\
\hline 9 & $\begin{array}{l}\text { Kejelasan kegiatan } \\
\text { inti }\end{array}$ & 5 & Sangat baik \\
\hline 10 & $\begin{array}{l}\text { Kejelasan kegiatan } \\
\text { penutup }\end{array}$ & 5 & Sangat baik \\
\hline 11 & $\begin{array}{lr}\text { Penyajian draft } & \text { drajel pembelajaran } \\
\text { model } & \text { sesuai dengan } \\
\text { kearifan lokal dan } \\
\text { karakter }\end{array}$ & 4 & Baik \\
\hline \multicolumn{4}{|c|}{ BAHASA DAN FORMAT PENULISAN } \\
\hline 12 & $\begin{array}{l}\text { Penyajian Model } \\
\text { Pembelajaran Jelas }\end{array}$ & 4 & Baik \\
\hline 13 & $\begin{array}{l}\text { Penyajian Model } \\
\text { Pembelajaran } \\
\text { Dikemas Secara } \\
\text { Menarik }\end{array}$ & 4 & Baik \\
\hline $\begin{array}{c}\text { Skor } \\
\text { penilaian } \\
\text { total }\end{array}$ & & 4.23 & Baik \\
\hline
\end{tabular}

Hasil penilaian oleh validator ahli materi mendapatkan skor rata-rata 4,23. Berdasarkan hasil konversi skor validasi tersebut, didapatkan kriteria "Baik". Sedangkan untuk draft awal buku panduan model pembelajaran multirepresentasi berbasis kearifan lokal terdapat empat komponen, yaitu komponen kelayakan isi, komponen kebahasaan, komponen penyajian, dan komponen kegrafikaan. Adapun hasil penilaian yang didapatkan dari ahli adalah sebagai berikut.

Tabel 2. Hasil Validasi Ahli Terhadap

Produk Buku Panduan Model

Pembelajaran Multirepresentasi

Berbasis Kearifan Lokal

\begin{tabular}{clccccc}
\hline No & $\begin{array}{l}\text { Komponen } \\
\text { Penilaian }\end{array}$ & $\begin{array}{c}\text { Jumlah } \\
\text { Item }\end{array}$ & $\begin{array}{c}\text { Jumlah } \\
\text { Skor }\end{array}$ & $\mathbf{M}_{i}$ & $\mathbf{S D}_{i}$ & $\begin{array}{c}\text { Kriteria } \\
\text { Penilaian }\end{array}$ \\
\hline 1 & $\begin{array}{l}\text { Komponen } \\
\text { Kelayakan } \\
\text { Isi }\end{array}$ & 9 & 27 & 22,5 & 4,5 & Baik \\
\hline 2 & $\begin{array}{l}\text { Komponen } \\
\text { Kebahasaan }\end{array}$ & 4 & 14 & 10 & 2 & $\begin{array}{c}\text { Sangat } \\
\text { Baik }\end{array}$ \\
\hline 3 & $\begin{array}{l}\text { Komponen } \\
\text { Penyajian }\end{array}$ & 8 & 23 & 20 & 4 & Baik \\
\hline 4 & $\begin{array}{l}\text { Komponen } \\
\text { Kegrafikaan }\end{array}$ & 4 & 14 & 10 & 2 & $\begin{array}{c}\text { Sangat } \\
\text { Baik }\end{array}$ \\
\hline Jumlah & 25 & 78 & 62,5 & 12,5 & - \\
\hline
\end{tabular}

Dari rumusan di atas, maka dapat disimpulkan bahwa secara keseluruhan, draft buku panduan model pembelajaran multirepresentasi berbasis kearifan lokal mendapatkan kriteria "Baik".

Selain penilaian, komentar dan saran dari ahli juga dibutuhkan untuk perbaikan draft buku panduan model pembelajaran multirepresentasi. Validator memberikan koreksi terhadap beberapa kegiatan seperti kegiatan dolanan anak "benthik" perlu dimodifikasi yang sesuai dengan karakteristik anak usia 5-6 tahun. Setelah menerima masukan dan revisi dari ahli, maka langkah selanjutnya adalah melakukan revisi awal pada draft produk. Revisi dilakukan untuk memperbaiki draft produk sebelum diujicobakan. 


\section{Uji Kelayakan}

\section{a. Hasil Uji Coba Terbatas}

Pelaksanaan uji coba terbatas dilakukan untuk mengetahui respon guru terhadap buku panduan model pembelajaran multirepresentasi setelah menggunakannya sebagai sumber pembelajaran di Taman Kanak-kanak. Uji coba terbatas ini dilakukan selama 1 minggu di TK ABA Godegan. Sampel yang digunakan dalam uji coba terbatas ini adalah 2 guru, serta melibatkan 20 peserta didik.

Pada uji coba terbatas, sebelum guru menilai buku panduan model pembelajaran multirepresentasi. Hal ini dilakukan agar guru dapat menilai kepraktisan dari buku dan mengetahui langsung apa kekurangan dari buku panduan. Rekapitulasi hasil respon guru terhadap buku panduan model pembelajaran multirepresentasi ditunjukkan pada tabel 3 berikut.

Tabel 3. Hasil Respon Guru Terhadap

Buku Panduan Model Pembelajaran Multirepresentasi Pada Uji Coba

Terbatas

\begin{tabular}{cccccccc}
\hline No & $\begin{array}{l}\text { Komponen } \\
\text { Penilaian }\end{array}$ & $\begin{array}{c}\text { Jumlah } \\
\text { Item }\end{array}$ & $\begin{array}{c}\text { Sub } \\
\text { Total }\end{array}$ & $\overline{\boldsymbol{M}}$ & $\boldsymbol{M}_{\boldsymbol{i}}$ & $\begin{array}{c}\boldsymbol{S D} \\
\boldsymbol{i}\end{array}$ & $\begin{array}{c}\text { Kriteria } \\
\text { Penilaian }\end{array}$ \\
\hline 1 & $\begin{array}{l}\text { Komponen } \\
\text { Kelayakan } \\
\text { Isi }\end{array}$ & 9 & 145 & 29 & 22,5 & 4,5 & Baik \\
\hline 2 & $\begin{array}{l}\text { Komponen } \\
\text { Kebahasaan }\end{array}$ & 4 & 61 & 12,2 & 10 & 2 & Baik \\
\hline 3 & $\begin{array}{l}\text { Komponen } \\
\text { Penyajian }\end{array}$ & 6 & 96 & 19,2 & 15 & 3 & Baik \\
\hline 4 & $\begin{array}{l}\text { Komponen } \\
\text { Kegrafikaan }\end{array}$ & 3 & 47 & 9,4 & 7,5 & 1,5 & $\begin{array}{c}\text { Sangat } \\
\text { Baik }\end{array}$ \\
\hline Skor Total & 22 & 349 & 69,8 & 55 & 11 & - \\
\hline
\end{tabular}

Dari rumusan di atas, dapat disimpulkan bahwa pada uji coba terbatas, secara keseluruhan buku panduan model pembelajaran multirepresentasi mendapatkan kriteria "Baik".

\section{b. Hasil Uji Coba Lapangan}

Uji coba lapangan dilakukan untuk mengetahui efektivitas buku panduan yang dikembangkan pada guru dengan jumlah yang lebih luas. Uji coba dilakukan di TK ABA Kembaran.
Sampel yang digunakan dalam uji coba terbatas ini adalah 5 guru, serta melibatkan kurang lebih 40 peserta didik. Rekapitulasi hasil respon guru terhadap buku panduan model pembelajaran multirepresentasi ditunjukkan pada tabel 4 berikut.

Tabel 4. Hasil Respon Guru Terhadap

Buku Panduan Model Pembelajaran

Multirepresentasi Pada Uji Coba

$$
\text { Lapangan }
$$

\begin{tabular}{cccccccc}
\hline No & $\begin{array}{c}\text { Komponen } \\
\text { Penilaian }\end{array}$ & $\begin{array}{c}\text { Jumlah } \\
\text { Item }\end{array}$ & $\begin{array}{c}\text { Sub } \\
\text { Total }\end{array}$ & $\overline{\boldsymbol{M}}$ & $\boldsymbol{M}_{\boldsymbol{i}}$ & $\begin{array}{c}\boldsymbol{S D} \\
\boldsymbol{i}\end{array}$ & $\begin{array}{c}\text { Kriteria } \\
\text { Penilaian }\end{array}$ \\
\hline 1 & $\begin{array}{l}\text { Komponen } \\
\text { Kelayakan } \\
\text { Isi }\end{array}$ & 9 & 291 & 29,1 & 22,5 & 4,5 & Baik \\
\hline 2 & $\begin{array}{l}\text { Komponen } \\
\text { Kebahasaan }\end{array}$ & 4 & 126 & 12,6 & 10 & 2 & Baik \\
\hline 3 & $\begin{array}{l}\text { Komponen } \\
\text { Penyajian }\end{array}$ & 6 & 198 & 19,8 & 15 & 3 & $\begin{array}{c}\text { Sangat } \\
\text { Baik }\end{array}$ \\
\hline 4 & $\begin{array}{l}\text { Komponen } \\
\text { Kegrafikaan }\end{array}$ & 3 & 103 & 10,3 & 7,5 & 1,5 & $\begin{array}{c}\text { Sangat } \\
\text { Baik }\end{array}$ \\
\hline Skor Total & 22 & 718 & 71,8 & 55 & 11 & \\
\hline
\end{tabular}

Dari rumusan di atas, maka dapat disimpulkan bahwa pada uji coba lapangan, secara keseluruhan buku panduan model pembelajaran multirepresentasi mendapatkan kriteria "Sangat Baik".

\section{Uji Efektivitas}

Untuk mengetahui ada tidaknya perbedaan pencapaian indicator cinta tanah air pada kelas control dan kelas eksperimen dilakukan dengan uji-t independen (independent sample $t$-test). Uji-t independen untuk menguji hipotesis penelitian berikut:

Ho: Tidak terdapat perbedaan pencapaian indicator cinta tanah air pada peserta didik yang gurunya menerapkan model pembelajaran multirepresentasi berbasis kearifan lokal.

Ha: Terdapat perbedaan pencapaian indicator cinta tanah air pada peserta didik yang gurunya menerapkan model pembelajaran 
multirepresentasi berbasis kearifan lokal.

Rangkuman data hasil perhitungan uji-t independen untuk indicator cinta tanah air peserta didik pada tabel 5 .

Tabel 5. Uji-t Independen Karakter Cinta Tanah Air Pada Kelas Kontrol dan Kelas Eksperimen

\begin{tabular}{l|c|c|c|c}
\hline Kelas & $\begin{array}{c}\text { Rata-rata } \\
\text { Skor }\end{array}$ & N & $\begin{array}{c}\text { Sig. } \\
(\mathbf{p})\end{array}$ & Keterangan \\
\hline KK & 13,5652 & 22 & 0,000 & Ho ditolak \\
KE & 19,8636 & 22 & \\
\hline
\end{tabular}

Berdasarkan tabel diketahui bahwa nilai signifikansi untuk indikator cinta tanah air pada peserta didik adalah 0,000 atau kurang dari 0,05 sehingga Ho ditolak dan Ha diterima. Jadi terdapat perbedaan karakter cinta tanah air pada peserta didik yang gurunya menerapkan model pembelajaran multirepresentasi berbasis kearifan lokal.

\section{SIMPULAN}

Berdasarkan penelitian dan pengembangan yang dilaksanakan, dapat disimpulkan bahwa:

1. Model pembelajaran multirepresentasi berbasis kearifan lokal yang sesuai bagi pendidik peserta didik usia 5-6 tahun adalah model pembelajaran yang berdasarkan pada tiga komponen yaitu komponen materi, sintaks, Bahasa dan format penulisan. Pada uji coba lapangan, buku panduan model pembelajaran multirepresentasi mendapatkan kriteria "Sangat Baik". Hal ini menunjukkan bahwa buku panduan model pembelajaran multirepresentasi layak digunakan oleh guru sebagai panduan dalam menerapkan pembelajaran kearifan lokal.

2. Model pembelajaran multirepresentasi berbasis kearifan local terbukti efektif untuk membentuk karakter cnta tanah air peserta didik usia 5-6 tahun.

\section{DAFTAR PUSTAKA}

[1] Battistich, V. 2011. Character Education, Prevention, and Positive Youth Development. University of Missouri, St. Louis.

[2] Lickona, T., Schaps, E., \& Lewis, C. 2003. CEP's Eleven Principles of Effective Character Education. Washington, DC: Character Education Partnership.

[3] Ainsworth, Sharoon. (1999). The Function of Multiple Representation, Jurnal Computer and Education, 131152.

[4] Wu-Yuin Hwang, dkk. (2007). Multiple Representation Skills and Creativity Effects on Mathematical Problem Solving using a Multimedia Whiteboard System, Jurnal Educational Technology \& Society, 10 (2), 191-212.

[5] Mungmachon, M, S. (2012). Knowledge and Local Wisdom: Community Treasure, International Journal of Humanities and Social Science, 2 (13), 174-181.

[6] Sajdim, Umar, M. (2015). Pengembangan dan Pembinaan Nilai-Nilai Bhineka Tunggal Ika dan Kearifan Lokal Berbasis Learning Society di Ternate. Universitas Negeri Yogyakarta: Disertasi. 
[7] Borg, W. R., \& Gall, M. D. (2007). Educational research an introduction. New York: Pearson Education, Inc.

[8] Peraturan Menteri Pendidikan dan Kebudayaan Republik Indonesia Nomor 137 Tahun 2014 tentang Standar Nasional Pendidikan Anak Usia Dini. 